\title{
The Influence Of Perceived Product Quality And Perceived Service Quality Toward Customer Value, Behavior Intention And Customer Response Residential Area In South Kalimantan Province
}

\author{
Sutrisno \\ Doctoral Student of Economic and Business. \\ University of 17 August 1945 Surabaya \\ Ujianto \\ University of 17 August 1945 Surabaya \\ Slamet Riyadi \\ University of 17 August 1945 Surabaya
}

\begin{abstract}
The research aims to analyze the influence of Perceived Product Quality And Perceived Service Quality Toward Customer Value, Behavior Intention And Customer Response Residential Area In South Kalimantan Province. The population in this research is the customer Residential Area In South Kalimantan Province. Sampling technique by using accidental sampling with selected respondents must meet predetermined criteria standards. because the population is very much. The number of samples as many as 120 responden, this was according to Ferdinand (2002:48). The analysis was using SPSS and using AMOS 20.0 software. The test results showed that only six hypothesis have a significant effect, namely: Perceived product quality significantly influence toward customer value in Residential Area In South Kalimantan Province, Perceived service quality significantly influence toward customer value in Residential Area In South Kalimantan Province, Perceived product quality significantly influence toward behavior intention customer in Residential Area In South Kalimantan Province, Perceived service quality significantly influence toward behavior intention customer in Residential Area In South Kalimantan Province, customer value significantly influence toward customer respon in Residential Area In South Kalimantan Province, customer intention significantly influence toward customer respon in Residential Area In South Kalimantan Province. While three other hypothesis have not significant namely: customer value have not significant influence to customer intention in Residential Area In South Kalimantan Province, perceived product quality have not significantly influence to customer response in Residential Area In South Kalimantan Province and perceived service quality have not significant influence toward customer response in Residential Area In South Kalimantan Province.
\end{abstract}

Keywords: Product Quality, Service Quality, Customer Value, Behavior Intention, Customer Response

\section{INTRODUCTION}

Residential development is strongly influenced from two sides, namely the demand side, residential is part of the basic human needs, so that the growth of the population has a very strong correlation to the growth in demand for residential. On the supply side, residential development will be driven by three main actors, namely the government, the private sector and the community. Based on data from the Central Statistics Agency for 2017 the population 
of Indonesia is 261.8 million with a population growth rate of $1.3 \%$ per year, with residential needs reaching 800 thousand more units per year.

Based on data from the Regional Representative Council of REI, South Kalimantan Province, the number of residential development companies in the last 3 (three) years 2016-2018 for the type of houses built consisted of house types: type 36, type 45, type 72 , type 100 , type 120 , type 140, type 150, type 160 and type 180. Of the many types of houses built, the most type 36 reached 76 percent. For this reason the authors are interested in examining consumers who buy the most type 36 housing.

The buyer's perspective in making a decision to buy a product, namely by considering the quality of the product and the quality of service. Do both provide value for customers and also direct customer behavior intention to respond / buy the product. Responses usually play a major role in shaping behavior. In many cases the response to a particular product often affects consumers to make a purchase or not. According to Tjiptono (2000: 54) product quality has a close relationship with behavioral intention. Buyers who will buy housing products try to get the highest customer value. The highest customer value will provide customer response to their needs and desires.

Therefore, housing developers always try to deliver the best products and services to buyers in order to provide customer value and customer response so that their needs and desires can be met. This is in accordance with Wahyuningsih Study (2012) states that customer value has a close relationship with behavioral intention. Consumers who receive a higher level of value have a stronger behavior intention to recommend it to others.

\section{LITERATURE REVIEW AND HYPOTESIS}

The American Marketing Association (in his book J. Paul Peter and Jerry C. Olson, 1999: 6), defines consumer behavior as a dynamic interaction between influence and cognition, behavior and events around us where humans carry out aspects of exchange in their lives. There are three important ideas in the above definition: (1) consumer behavior is dynamic; (2) it involves the interaction between influence and cognition, behavior and events around; and (3) it involves an exchange.

According to Zeithaml (1988: 5) quality is a form of a comprehensive assessment of a product. suggests that there are two kinds of quality, namely: 1) Affective Quality, which is perceived quality as a form of comprehensive assessment of a product or an assessment that is global in nature. 2) Cognitive Quality, which is a conclusion about quality based on low-level cues and overall product evaluation. The definition of service is a utility that can be separately identified and basically intended to meet the needs and desires of the customer. The definition of service is as follows: "A servise is any act or performance that one party can offer to another that essentially intangible and does not result in the ownership of anything. It's production may not be tied to a physical product" (Kotler, 1999).

Parasuraman, Berry and Zeithaml in Lupiyoadi (2001) stated that there are five dimensions that determine service quality from the customer's point of view, namely: a) Reliability to provide the promised service immediately and accurately to the customer. b) Responsiveness, which is a response / readiness owned by employees and company leaders in helping consumers and providing services that are fast and responsive. c) Assurance, namely the ability of employees to appropriately know the product, the skills in providing information and the ability to instill consumer confidence in the company. d) Empathy is individual attention given by the company to consumers such as the ease of contacting the company or the ability of 
employees to communicate with customers and the company's business to understand the wants and needs of customers. e) Tangibles, namely physical evidence of services that include physical facilities, equipment, employees and means of communication.

According to Albrecht (1994) the seven elements that make up the infrastructure in the delivery of customer value are: 1) Environmental: the place or physical atmosphere where customer experience can occur, factors that must be considered include: location, access, security and comfort as well provide customers' special needs. 2) Sensory: five sensory experiences that are directly encountered by the customer. These elements include what is seen, what is heard, feelings, physical sensations, emotional reactions, aesthetic characteristics of merchandise items, as well as feelings that include the psychological scope of the customer's environment. 3) Interpersonal: customer interaction with employees and also with other customers as a whole experience. 4) Deliverable: everything related to the customer physically during the service. This concerns everything related to the customer physically, received and experienced by the customer during the experience of using service benefits, even if it is temporary. 5) Procedural: procedures required by customers to do business with a business entity. The procedural element relates to a series of processes and procedures that companies create to serve customers. 6) Informational: aspects of the customer experience involved in the effort to obtain information needed by the customer. 7) Financial: the price paid by the customer for all the experience he obtained

Initially Ajzen and Fishbein in Dharmmesta (2000: 45) put forward a famous theory called Theory of Reasoned Action that connects attitudes, subjective norms, intentions and behavior. Then developed the theory of Planned Behavior which is the development of the theory of Reasoned Action by Ajzen in 1985 (Dharmmesta, 2000: 46). Theory of Planned Behavior is different from Theory of Reasoned Action. The difference lies in the perceived behavioral control variable, which indicates the ease or difficulty of taking actions that are considered a reflection of the past in addition to anticipated obstacles or obstacles, where these variables are not found in the Theory of Reasoned Action. Theory of Planned Behavior explains behavioral control variables that are felt to influence intentions and directly influence behavior (Ajzen in Dharmmesta, 2000: 47).

According to Loudon and Bitta (2003: 45) responses are formed from three components namely cognitive, affective and conative. The cognitive component describes the consumers' perceptions, consumers' opinions, consumers' comparisons of objects and about the characteristics of the brand itself. Affective component describes the feelings of consumers, consumer emotions, consumer evaluation and the level of the brand itself. While the conative component explains about consumer tendencies, consumer goals, consumer preferences for an object and consumer loyalty to certain brands. This is what determines how a consumer's response can provide a decision in purchasing a product.

\section{Research Hypothesis}

Based on the background of the problem, problem formulation, literature review and conceptual framework, the research hypotheses are arranged as follows: 1) Perceived product quality significantly influences the customer value of residential in South Kalimantan Province; 2) Perceived of product quality has a significant effect on the customer response of residential in South Kalimantan Province; 3) Perceived of product quality has a significant effect on behavior intention in residential customers in South Kalimantan Province; 4) Perceived of service quality has a significant effect on the customer value of residential in South Kalimantan Province; 5) Perceived of service quality has a significant effect on the 
customer response of residential in South Kalimantan Province; 6) Perceived of service quality has a significant effect on behavior intention; 7) Customer value has a significant effect on the response of residential customers in South Kalimantan Province; 8) Customer value has a significant effect on the behavior intention in residential in South Kalimantan Province; 9) Behavior intention has a significant effect on the customer response of residential in South Kalimantan Province.

\section{RESEARCH METHODE}

Sugiono (2004: 55) states, the population is a generalization area consisting of objects or subjects that have a certain quantity and characteristics determined by researchers to be studied and then drawn conclusions. In this study, the population is all residential consumers who buy houses from the beginning (first person) for type 36 housing in South Kalimantan Province.

The research sample must be able to represent the state of the population, which means the data obtained is sample data. Sugiono (2004: 56) said, the sample is a portion of the number and characteristics possessed by the population. What is learned from the sample, the conclusion will apply to the population. For this reason, the sample that is applied must be truly representative. In this study the number of indicators is 24 times 5 equal to 120 . So the number of samples to be used in this study are 120 residential consumers in South Kalimantan Province. In this study the sampling technique is non probability sampling, namely purposive sampling technique. According to Sugiyono (2010), purposive sampling is a technique for determining research samples with certain considerations with the aim that the data obtained can be more representative later. This explanatory research using Structural Equation modeling (SEM) method to analyze the data.

\section{ANALYSIS AND DISCUSSION}

The results of the calculation of the values of goodness of fit indexes produced by the structural model are as follows:

\section{Conformity Index Model on Structural Model}

\begin{tabular}{|c|c|c|c|}
\hline Goodness of Fit Index & Cut off Value & model results & information \\
\hline Probability Chi-Square & $\geq 0,05$ & 0,000 & Not Fit \\
\hline CMIN/DF & $\leq 2,0$ & 1,618 & Fit \\
\hline GFI & $\geq 0,90$ & 0,809 & Marginal \\
\hline AGFI & $\geq 0,90$ & 0,765 & Not Fit \\
\hline CFI & $\geq 0,90$ & 0,887 & Marginal \\
\hline TLI & $\geq 0,90$ & 0,872 & Marginal \\
\hline RMSEA & $\leq 0,08$ & 0,072 & Fit \\
\hline
\end{tabular}

The calculation results show that the overall suitability of the model has given the index index is still not in accordance with the recommended.

The results of the model modification using the theoretical guidelines and modification index are presented in Figure below: 


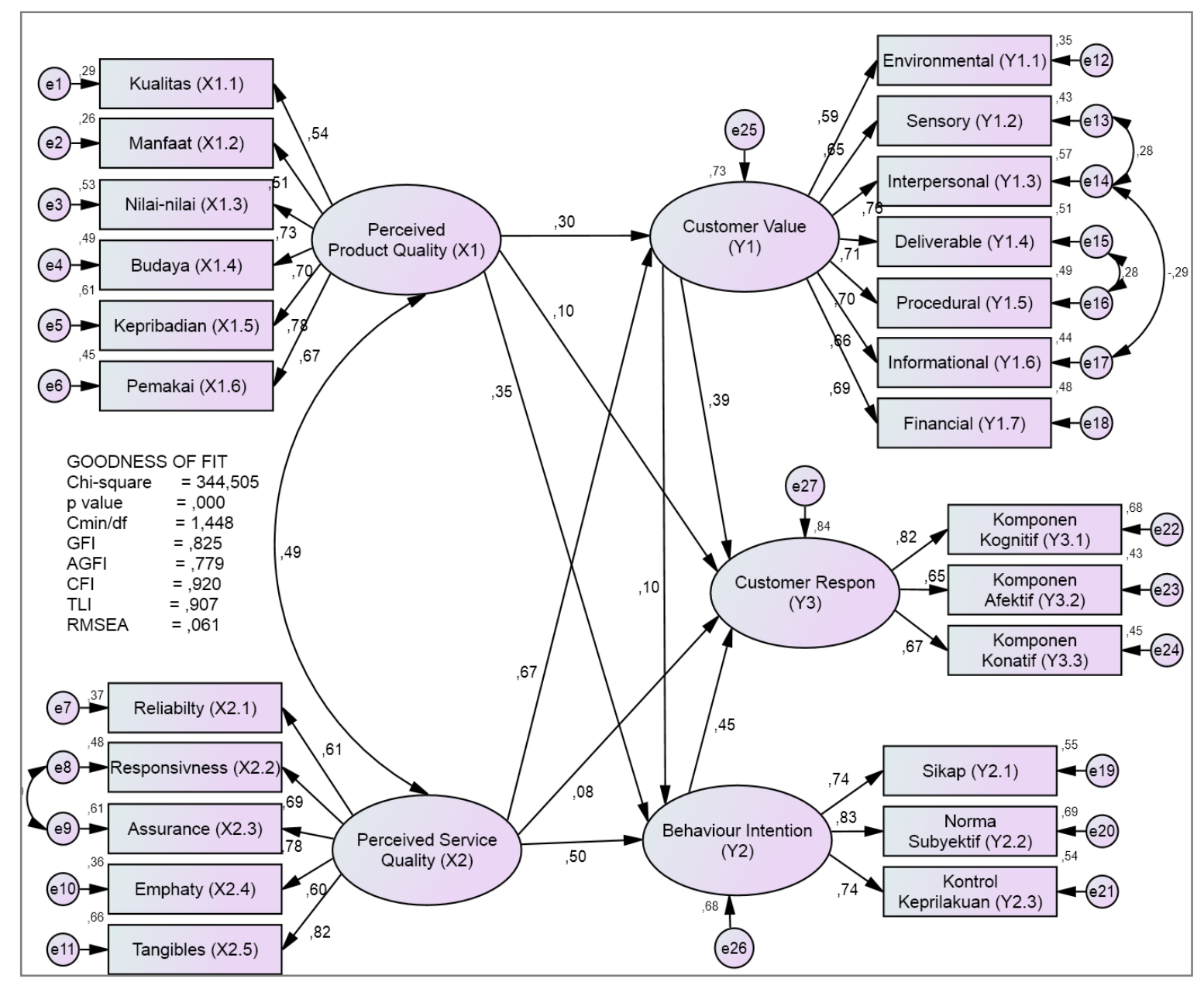

Modification Model

The results of the calculation of the goodness of fit index values resulting from the modification model are as follows:

Nilai Goodness of Fit dan Cut off Value Modification Model

\begin{tabular}{|c|c|c|c|}
\hline Criteria & $\begin{array}{c}\text { Test Results } \\
\text { Model }\end{array}$ & $\begin{array}{c}\text { Critical } \\
\text { Values }\end{array}$ & Informations \\
\hline Probability Chi-Square & $\geq 0,05$ & 0,001 & Not Fit \\
\hline CMIN/DF & $\leq 2,0$ & 1,448 & Fit \\
\hline GFI & $\geq 0,90$ & 0,825 & Marginal \\
\hline AGFI & $\geq 0,90$ & 0,779 & Not Fit \\
\hline CFI & $\geq 0,90$ & 0,920 & Fit \\
\hline TLI & $\geq 0,90$ & 0,907 & Fit \\
\hline RMSEA & $\leq 0,08$ & 0,061 & Fit \\
\hline
\end{tabular}

The results of the modification of the model show that the criteria for model conformity (goodness of fit) Cmin / df, RMSEA, GFI, CFI, and TLI have given a good index (fit or marginal) and show a better goodness of fit value than the previous model.

\section{Hypothesis test}

Using Structural Equation Modeling, then data is analized and the result as below : 
Testing the Structural Equation Hypothesis

\begin{tabular}{|c|c|c|c|c|c|c|}
\hline \multicolumn{3}{|c|}{ Causality Relationship } & \multirow{2}{*}{$\begin{array}{c}\text { Estimate } \\
0,301\end{array}$} & \multirow{2}{*}{$\begin{array}{c}\begin{array}{c}\text { Critical } \\
\text { Ratio }\end{array} \\
2,829\end{array}$} & \multirow{2}{*}{$\begin{array}{c}\text { P-Value } \\
0,005\end{array}$} & \multirow{2}{*}{$\frac{\text { Informasin }}{\text { Significant }}$} \\
\hline $\begin{array}{l}\text { Perceived of product } \\
\text { quality(X1) }\end{array}$ & $\rightarrow$ & $\begin{array}{l}\text { Customer Value } \\
\text { (Y1) }\end{array}$ & & & & \\
\hline $\begin{array}{l}\text { Perceived of service } \\
\text { quality (X2) }\end{array}$ & $\rightarrow$ & $\begin{array}{l}\text { Customer Value } \\
\text { (Y1) }\end{array}$ & 0,666 & 4,599 & 0,000 & Significant \\
\hline $\begin{array}{l}\text { Perceived of product } \\
\text { quality(X1) }\end{array}$ & $\rightarrow$ & $\begin{array}{l}\text { Behavior Intention } \\
\text { (Y2) }\end{array}$ & 0,349 & 2,705 & 0,007 & Significant \\
\hline $\begin{array}{l}\text { Perceived of service } \\
\text { quality (X2) }\end{array}$ & $\rightarrow$ & $\begin{array}{l}\text { Behavior Intention } \\
\text { (Y2) }\end{array}$ & 0,497 & 2,647 & 0,008 & Significant \\
\hline Nilai Pelanggan (Y1) & $\rightarrow$ & $\begin{array}{l}\text { Behavior Intention } \\
\text { (Y2) }\end{array}$ & 0,103 & 0,517 & 0,605 & $\begin{array}{c}\text { Not } \\
\text { Significant }\end{array}$ \\
\hline $\begin{array}{l}\text { Perceived of Product } \\
\text { quality(X1) }\end{array}$ & $\rightarrow$ & $\begin{array}{l}\text { Customer Respon } \\
\text { (Y3) }\end{array}$ & 0,096 & 0,779 & 0,436 & $\begin{array}{c}\text { Not } \\
\text { Significant }\end{array}$ \\
\hline $\begin{array}{l}\text { Perceived of service } \\
\text { quality (X2) }\end{array}$ & $\rightarrow$ & $\begin{array}{l}\text { Customer Respon } \\
\text { (Y3) }\end{array}$ & 0,076 & 0,413 & 0,680 & $\begin{array}{c}\text { Not } \\
\text { Significant }\end{array}$ \\
\hline Customer Value (Y1) & $\rightarrow$ & $\begin{array}{l}\text { Customer Respon } \\
\text { (Y3) }\end{array}$ & 0,393 & 2,035 & 0,042 & Significant \\
\hline $\begin{array}{l}\text { Behavior Intention } \\
\text { (Y2) }\end{array}$ & & $\begin{array}{l}\text { Customer Respon } \\
\text { (Y3) }\end{array}$ & 0,453 & 2,680 & 0,007 & Significant \\
\hline
\end{tabular}

\section{The table above shows that:}

1. The variable perceived product quality significantly influences customer value, with a critical ratio of $2.829>1.96$ and $p$-value of $0.005<5 \%$, it can be concluded that there is a significant influence on the perceived product quality to customer value. So the hypothesis which states that the perceived of product quality has a significant effect on customer value in residential customers in the province of South Kalimantan can be accepted.

2. The perceived service quality variable has a significant effect on customer value, with a critical ratio of 4.599> 1.96 and a p-value of $0.000<5 \%$, it can be concluded that there is a significant influence on the perceived service quality to customer value. So the hypothesis which states that the perceived of service quality has a significant effect on the value of residential customers in the province of South Kalimantan can be accepted.

3. The perceived product quality variable has a significant effect on behavior intention, with a critical ratio of $2.705>1.96$ and a p-value of $0.007<5 \%$, it can be concluded that there is a significant influence on the perceived product quality towards behavior intention. So the hypothesis which states that the perceived of product quality has a significant effect on behavior intention in residential customers in South Kalimantan can be accepted.

4. The perceived service quality variable has a significant effect on behavior intention, with a critical ratio of $2.647>1.96$ and a p-value of $0.008<5 \%$, so it can be concluded that there is a significant influence on the perceived service quality of behavior intention. So the hypothesis which states that the perceived of service quality has a significant effect on the behavior intention in residential customers in the province of South Kalimantan can be accepted.

5. Variable customer value has no significant effect on behavior intention, with a critical ratio of $0.517<1.96$ and p-value of $0.605>5 \%$, it can be concluded that there is no significant effect on customer value of behavior intention. So the hypothesis which states that customer value has a significant effect on the behavior intention in residential customers in South Kalimantan province cannot be accepted.

6. The perceived product quality variable has no significant effect on customer response, with a critical ratio of $0.779<1.96$ and p-value of $0.436>5 \%$, it can be concluded that 
there is no significant effect of perceived product quality to customer response. So the hypothesis which states that the perceived of product quality has a significant effect on the response of residential customers in the province of South Kalimantan cannot be accepted.

7. The perceived service quality variable has no significant effect on customer response, with a critical ratio of $0.413<1.96$ and a p-value of $0.680>5 \%$, it can be concluded that there is no significant effect of perceived service quality to customer response. So the hypothesis which states that the perceived of service quality has a significant effect on the response of residential customers in the province of South Kalimantan cannot be accepted.

8. Variable customer value has a significant effect on customer response, with a critical ratio of $2.035>1.96$ and a p-value of $0.042<5 \%$, it can be concluded that there is a significant influence on customer value to customer response. So the hypothesis which states that customer value has a significant effect on the response of residential customers in the province of South Kalimantan can be accepted.

9. The variable behavior intention significantly influence customer response, with a critical ratio of $2.680>1.96$ and p-value of $0.007<5 \%$, it can be concluded that there is a significant influence of behavior intention to customer response. So the hypothesis stating that behavior intention has a significant effect on the response of residential customers in the province of South Kalimantan can be accepted.

\section{SUMMARY}

1) There is a significant influence on the perceived product quality to customer value. So the hypothesis which states that the perception of product quality has a significant effect on customer value in residential customers in the province of South Kalimantan can be accepted.

2) There is a significant influence on the perceived service quality to customer value. So the hypothesis which states that the perception of service quality has a significant effect on the value of residential customers in the province of South

Kalimantan can be accepted.

3) There is a significant influence on the perceived product quality towards behavior intention. So the hypothesis which states that the perceived of product quality has a significant effect on behavior intention in residential customers in South Kalimantan can be accepted.

4) There is a significant influence on the perceived service quality of behavior intention. So the hypothesis which states that the perceived of service quality has a significant effect on the behavior intention in residential customers in the province of South Kalimantan can be accepted.

5) There is no significant effect on customer value of behavior intention. So the hypothesis which states that customer value has a significant effect on the behavior intention in residential customers in South Kalimantan province cannot be accepted.

6) There is no significant effect of perceived product quality to customer response. So the hypothesis which states that the perceived of product quality has a significant effect on the customer response of residential in the province of South Kalimantan cannot be accepted.

7) There is no significant effect of perceived service quality to customer response. So the hypothesis which states that the perceived of service quality has a significant effect on the customer response of residential in the province of South Kalimantan cannot be accepted. 
8) There is a significant influence on customer value to customer response. So the hypothesis which states that customer value has a significant effect on the customer response of residential in the province of South Kalimantan can be accepted.

9) There is a significant influence of behavior intention to customer response. So the hypothesis stating that behavior intention has a significant effect on the customer response of residential in the province of South Kalimantan can be accepted.

\section{LIMITATION}

The limitations of this study are due to :

1. The theoritical basis that underline the relationship between independent variables, intervening variables dan dependent variable about the influence of perceived product quality and perceived service quality toward customer value, behavior intention and customer response, is still rarely studied beforehand.

2. This Dissertation analysis the influence of variables of perceived product quality and perceived service quality toward customer value, behavior intention and customer response residential area in south kalimantan province, while many other factors that influence customer response are still many that have not been revealed in this study.

3. The sincerity of the respondents when the research is conducted is things that are beyond the reach of researchers to control them.

4. This study examines hypotheses carried out together, meaning that they do not group each respondent based on the characteristics of respondents such as : education level, and work period, so it is not known whether there are differences in responses or evaluations of companies employees towards research variables.

\section{BIBLIOGRAFI}

Albrecht, S. L. 1994 Research and Practice : Hand Book of Employee Engagement Perspective, Issues, U,K : MGP Books Group

Dharmmesta, Basu Swasta, 2004, Loyalitas Pelanggan : Sebuah Kajian Konseptual sebagai Panduan Bagi Peneliti, Jurnal Ekonomi dan Bisnis Indonesi, Volume 14 Nomor 3 hal. 73-88

Ferdinand, A. 2002. Structural Equation Modeling Dalam Penelitian Manajemen: Aplikasi Model-Model Rumit Dalam Penelitian Untuk Tesis Magister dan Disertasi Doktor. Semarang: Penerbit Fakultas Ekonomi Universitas Diponegoro.

Fishbein and Ajzen, 1998, Belief, Attitude, Intentions and Behavior : An Introduction to theory and Research California : Addision- Wrsley Publishing Company, Inc

Kotler, Philip. 1992. Principles of marketing. Prentice Hall Internasional Inc, Englewood Cliffs WJ. and Amstrong, Gery, 2001, Prinsip-Prinsip Pemasaran, Erlangga, Jakarta and Kevin Lane Keller, 2006. Marketing Management, twelfth edition, New Jersey: Pearson Education, Inc. 2000, Marketing management. The Millennium Edition, Prentice Hall, USA.

, John T.B., and James C.M., 2006. Marketing for hospitality and tourism. Pearson International Edition, Fourth Edition, Pearson, Prentice Hall, Singapore.

Loudon, D.L and Della S. Bitta, 2003, Consumer Behavior Concept and Applications, Fourth Edition, McGraw Hill, Inc

Lupiyoadi, Rambat, 2001, Perilaku Konsumen, Penerbit Salemba Empat, Jakarta

Parasuraman, A., Zeithaml, V.A., and Berry, L.L. 1988. SERQUAL: A multiple item scale for measuring consumer perceptions of service quality. Journal of Retailing, vol. 64. no. 1. pp. 12-40.

Peter, P.J., and Olson J.C. 1999. Consumer behavior and marketing strategy. Fourth Edition, Richard D. Irwin, Inc. Terjemahan: Damos Sihombing. Jakarta: Penerbit Erlangga.

Raghubir, P. 2004. Coupons in context: discounting prices or decreasing profits?. Journal of Retailing, vol. 80, pp. 112. 
Riel, Van C.R.A., Lemmink J., and Streukens S. 2004. Boost customer loyalty with online support: the case of mobile telecoms providers. International Journal Internet Marketing And Advertising, vol. 1. no.1 pp. 4-23.

Rosenbaum, S.M. 2005. The symbolic servicescape: your kinds is welcome here. Journal of Consumer Behavior. vol. 4. no. 4. pp.249-261.

Seiders, K., Glenn B.V., Dhruv G., and Andrea L.G. 2005, Do satisfied customers buy more? examining moderating influence in a retailing context. Journal of Maketing, vol. 69. October, pp. 26-43.

Sengupta, S.K., and Pusateri. 2000. Empirical investigation of key account salesperson effetiveness. The Journal of Personal Selling and Sales Management, vol. 20. no. 4. pp. 253.

Sugiono, 2004, Metode Penelitian Bisnis, Cetakan ke delapan, Alfabeta, Bandung 1994. Metode Penelitian Bisnis, Alfabeta, Bandung

Tjiptono, F. 2000. Perspektif manajemen dan pemasaran kontemporer. Yogyakarta: Penerbit Andi.

Vadi, M. and Suurojam M. 2006. Training retail sales personnel in transition economies: applyinh a model of customer-oriented communication. Journal of Retailing and Consumer Services, vol. 13, pp. 339-349.

Van Dabholkar P.A., Shepherd C.D., and Dayle I.T. 2000. A comprehensive framework for service quality: an investigation of critical conceptual and measurement issues thought a longitudinal study. Journal of Retailing, vol. 76. no. 2. pp. 139-173.

Wahyuningsih, 2012, Metode Penelitian Manajemen, Badan Penerbit Universitas Diponegoro, Semarang

Wakefield, L.K. and Blodgett G.J. 1996. The effect of the servicescape on customer behavior intentions in leisure service setting. Journal of Services Marketing, vol. 10 no. 6. pp. 45-61.

Westbrook, R.A., and Oliver L.R. 1991. The dimensionality of consumption emotion patterns and customer satisfaction. Journal of Consumer Research, vol 18. pp. 84-91.

Yoon, M.H., and Suh J. 2003. Organizational citizenship behaviors and service quality as external effectiveness of contact employee. Journal of Business Research, vol. 56. pp. 597-611.

Zeithaml, V.A., 1988. Communication and control processes in the delivery of service quality. Journal of Marketing, vol. 52. no. 2. pp. 35-48.

Berry L.L. and Parasuraman A. 1996. The behavioral consequences of service quality. Journal of marketing, vol. 60. April, pp.31-46.

and Bitner Jo Mary. 2000. Service marketing: integrating customer focus across the firm. Second Edition, Boston: Irwin McGraw-Hill. Inc. USA.

, Valerie A. 2000. "Service Quality, Profitability, and the Economic Worth of Customers: What We Know and What We Need to Learns," Journal of the Academy of Marketing Science, Vol. 28 No. 1, pp.67-85. 